\title{
SUPPLEMENTARY REPORT: GEOLOGIC FEASIBILITY OF TALC AND SERPENTINITE BODIES FROM THE APPALACHIAN MOUNTAIN REGION OF EASTERN UNITED STATES WITH REGARD TO SITING OF RADIOACTIVE-WASTE REPOSITORIES
}

\author{
Part I - Additional Conclusions Relating \\ to Ultramafic Rocks
Part II - Field Investigations of Talc and Serpentinite Deposits

David B. Wenner

University of Georgia

Athens, Georgia 30602

January 1976

This report was prepared by D. B. Wenner under Consultant Subcontract 4496 with Union Carbide Corporation, Nuclear Division. The subcontract was administered by Oak Ridge National Laboratory.

\section{UNION OFFICE OF WASTE ISOLATION OAK RIDGE. TENNESSEE

This document was written as an informal report of an investigation. As such, it was not expected to conform to UCC-ND's scientific/technical standards for a formal report nor does it meet standards with respect to format, editing, composition or binding. It contains information which may be preliminary, fragmentary or of limited scope. The assumptions, views, and conclusions expressed in this document are those of the author and are not to be interpreted as those of Union Carbide Corporation, Nuclear Division, or USERDA. 


\section{DISCLAIMER}

This report was prepared as an account of work sponsored by an agency of the United States Government. Neither the United States Government nor any agency Thereof, nor any of their employees, makes any warranty, express or implied, or assumes any legal liability or responsibility for the accuracy, completeness, or usefulness of any information, apparatus, product, or process disclosed, or represents that its use would not infringe privately owned rights. Reference herein to any specific commercial product, process, or service by trade name, trademark, manufacturer, or otherwise does not necessarily constitute or imply its endorsement, recommendation, or favoring by the United States Government or any agency thereof. The views and opinions of authors expressed herein do not necessarily state or reflect those of the United States Government or any agency thereof. 


\section{DISCLAIMER}

Portions of this document may be illegible in electronic image products. Images are produced from the best available original document. 
This report was prepared as an account of work sponsored by the United States Government. Neither the United States nor the Energy Research and Development Administration, nor any of their employees, nor any of their contractors, subcontractors, or their employees, makes any warranty, express or implied, or assumes any legal liability or responsibility for the accuracy, completeness or usefulness of any information, annaratus, product or process disclused, or represents that its use would not infringe privately owned rights. 


\title{
SUPPLEMENTARY REPORT
}

\author{
GEOLOGIC FEASIBILITY OF TALC \\ AND SERPENTINITE BODIES FROM THE \\ APPALACHIAN MOUNTAIN REGION OF: \\ EASTERN UNITED STATES WITH REGARD \\ TO SITING OF RADIOACTIVE-WASTE REPOSITORIES
}

\section{Part I - Additional Conclusions Relating to Ultramafic Rocks
Part II - Field Investigations of Talc and Serpentinite Deposits

submitted to

Union Carbide Corporation

Oak Ridge National Laboratories

Oak Ridge, Tennessee 37830

Under Subcontract 4496

Prepared by

Dr. David B. Wenner

Department of Geology

University of Georgia

Athens, Georgia 30602

January, 1976 


\section{TABLE OF CONTENTS}

Topic/Item

Page

INTRODUCTION

1

PART I - ADDITIONAL CONCLUSIONS RELATING TO ULTRAMAFIC ROCKS

PART II - FIELD INVESTIGATIONS OF TALC AND SERPENTINITE DEPOSITS

CONCLUSIONS AND RECOMMENDATIONS

23

ACKNOWLEDGMENTS

REFERENCES CITED 


\section{Figures}

1 Index map of Vermont showing occurrences of ultramafic bodies and the locations of sites examined in this report.

2 Geologic map of the fifth level of the Eastern Magnesia Talc Company mine.

3 East-west geological cross section of the Eastern Magnesia Talc Company mine above level 5 .

\section{Plates}

1 View of the ceiling of a fifth level drift within the Eastern Magnesia Talc Company mine showing a remnant of dark-colored massive serpentinite in contact with lighter-colored schistose grit.

2 View within the Eastern Magnesia Talc Company mine at the end of a fifth level drift showing the grit-steatite-blackwall contact.

3 View of one side of a fifth level drift in the Eastern Magnesia Talc Company mine showing evidence of flowage and collapse of massive grit within a major fault zone.

View of the ceiling of a fifth level drift within the Eastern Magnesia Talc Company mine. This photograph shows ground water seepage, estimated to be only a few tens of drops per minute, from a major fault zone within the grit. 


\section{INTRODUCTION}

This report consists of a follow-up investigation of certain selected aspects covered in an earlier publication titled "Geologic Feasibility of Talc and Serpentinite Bodies from the Appalachian Mountain Region of Eastern United States With Regard to siting of Radioactive Waste Repositories" submitted November, 1975, by Drs: Wenner and Gonzales to Union Carbide Corporation, Oak Ridge National Laboratories. Due to the fact that few direct conclusions could be deduced in this study concerning the suitability of ultramafic rocks, additional information was obtained by visiting Dr. Maurice I. Morency of the Laboratoire de Geochimie, Department Des Sciences De La Terre, The University of Quebec at Montreal. He is currently conducting a similar study of this type for the Atomic Energy of Canada, Ltd. (AECL).

Further insight into the geological and structural features of serpentine and talc was also gained from on-site examination of surface and underground exposures. The field studies were concentrated in selected localities in Vermont and Maryland. These two regions were considered in the above mentioned report to be the most favorable localities for repository sites, due chiefly to the overall size of ultramafic bodies and the relatively low seismic risk potential of these areas:

The first part of this report contains a general assessment of information gained through conversations with Dr. Morency concerning the potential suitability of ultramafic rocks and serpentinites as a medium for containment of radioactive wastes. The 
second section represents some general observations and conclusions based upon six days of field examinations and related activities in Vermont and Maryland. These activities encompassed: (1) observations of surface exposures of large ultramafic bodies in the Missisquoi Valley Region of Vermont; (2) a subsurface examination at the Eastern Magnesia Talc Company mine near Johnson, Vermont; and (3) observations of exposures of talc and serpentine within several quarries and large outcrops from ultramafic bodies in Maryland.

Additional studies were made of several talc deposits in eastern California. These are included in this report principally in order to describe the geologic setting of metasedimentary-type talc deposits. Such associations are representative of the types of geologic environments in which most of this country's talc ores are currently being exploited (i.e., California, the Gouverneur District of New York, the Dillon-Ennis District of Montana, the Murphy District of North Carolina). 
ADDITIONAL CONCLUSIONS RELATING TO ULTRAMAFIC ROCKS

A great deal of information concerning the potential suitability of serpentine and ultramafic rocks for use as a disposal medium for radioactive wastes was gained from extensive discussions with Dr. Maurice L. Morency of the University of Quebec at Montreal. At the present time, Dr. Morency has a grant from the Atomic Energy of Canada, Ltd. (AECL) to investigate problems of this nature; his work, however, does not specifically include any such assessment for talc-bearing rocks. These studies involve both field and laboratory programs.

The field reconnaissance investigations encompassed studies of some of the large ultramafic bodies in the Appalachian Mountains in Canada and in the Precambrian shield. These field studies consisted of verifying the composition of mapped units, assessing the general distribution of serpentine in the ultramafic rocks, conducting a mineralogical classification of collected samples, and examining exposures of ultramafic rocks in deep mines.

In addition, laboratory investigations were made of some of the physical properties of a wide variety of ultramafic rock types. These included studies of the thermal stability of serpentinite and other minerals through DTA analysis, measurement of thermal conductivities, and evaluation of the coefficients of thermal expansion. Future investigations within Dr. Morency's laboratory will include studies of the effect of radiation upon 
the various physical properties of ultramafic rocks.

Preliminary conclusions from these studies suggest that ultramafic rocks and serpentinites may potentially make a favorable host rock for containment of radioactive waste. Some of these favorable factors are briefly outlined below.

(1) Serpentinized ultramafic bodies of large dimensions occur in a wide range of locations in both the United States and Canada. The detailed distribution of mineral compositions in most such units are not however well known, since various ultramafic rock types are normally not distinguished on geologic maps.: However, some of various kinds of ultramafic-rock types (i.e., dunites, peridotites, talc-carbonates, etc.) have been identified in the Missisquoi Region of. Vermont (Cady and others, 1963).

(2) Serpentine itself, the mineral with the lowest thermal stability commonly found associated with ultramafic bodies, is nevertheless stable to relatively high temperatures. DTA analysis, a kinetically controlled dehydration process, indicates serpentine is stable to $600-700^{\circ} \mathrm{C}$, although equilibrium stability temperatures are lower $\left(-500^{\circ} \mathrm{C}\right)$. . It is uncertain, however, which process is most appropriate in instances where heating occurs due to burial of radioactive waste in a subsurface environment.

(3) Ultramafic rocks in general have a relatively low thermal coefficient of expansion compared to many other rock types (i.e., granite). Thus, a buried heat source in an ultramafic rock medium would not be expected to generate radiating fractures to the same extent as would probably occur in many other rock types. Perhaps 
much of the spalling observed in deep mines and quarries in granite may be due to this factor. No such features were observed by $\mathrm{Dr}$. Morency in deep mines within ultramafic rocks.

(4) Serpentine offers the ability to undergo self-sealing at depth due to flowage and small-scale shearing, thus preventing ground water influx into the body itself. Artificial openings at the Thetford Mines of Quebec were described by $\mathrm{Dr}$. Morency as being. extremely dry at depths around 2600 feet and greater. In contrast, granites, which commonly contain large; through-going fractures to depths as great as 5000 feet, commonly allow deep circulation of ground waters.

(5) Ultramafic bodies that typically range in composition from unserpentinized dunites and peridotites to pure serpentinites offer a wide variation in physical properties and thus offer a variety of geological settings for containment of radioactive waste. For example, unserpentinized peridotite and dunite would appear to offer great strength, a low coefficient of thermal expansion, and high thermal stability (greater than $1000^{\circ} \mathrm{C}$ ). In contrast, pure serpentinite exhibits properties of self-sealing and flowage which would effectively seal all fracture zones. 
PART II

\section{FIELD INVESTIGATIONS OF TALC AND SERPENTINITE DEPOSITS}

The Missisquoi Valley and Vicinity, Vermont

The regional geologic setting of the Missisquoi Valley Region of Vermont has been described in detail by Cady and others (1963). Within this region, there exist many relatively large ultramafic bodies (see Figure 1 ) consisting of dominantly unserpentinized dunites with minor peridotites, massive and sheared serpentinites, and talc carbonates and steatites. These types are in part distinguished on cady and others' geologic map.

Typically many of the ultramafic bodies composed of dunite and peridotite exhibit complex intergradational relationships with massive serpentinite on both a large and very small scale. Many. such bodies contain rims of talc-carbonate (grit) with an outer periphery of steatite (pure talc) in contact with the country rock. Several talc-carbonate units in this area are sufficiently large enough as to form mappable units. The largest such unit, which lies about one mile east of the village of Troy (see Figure 1), is up to 3000 feet in width and extends approximately four miles in length.

Exposures from this body were examined along state Route 100, approximately one mile east of Troy, and along an unpaved road approximately one mile southeast of Troy. Outcrops of talccarbonate rock are not exposed in either location except as float along road cuts and in stream gullies. The talc-carbonate body 


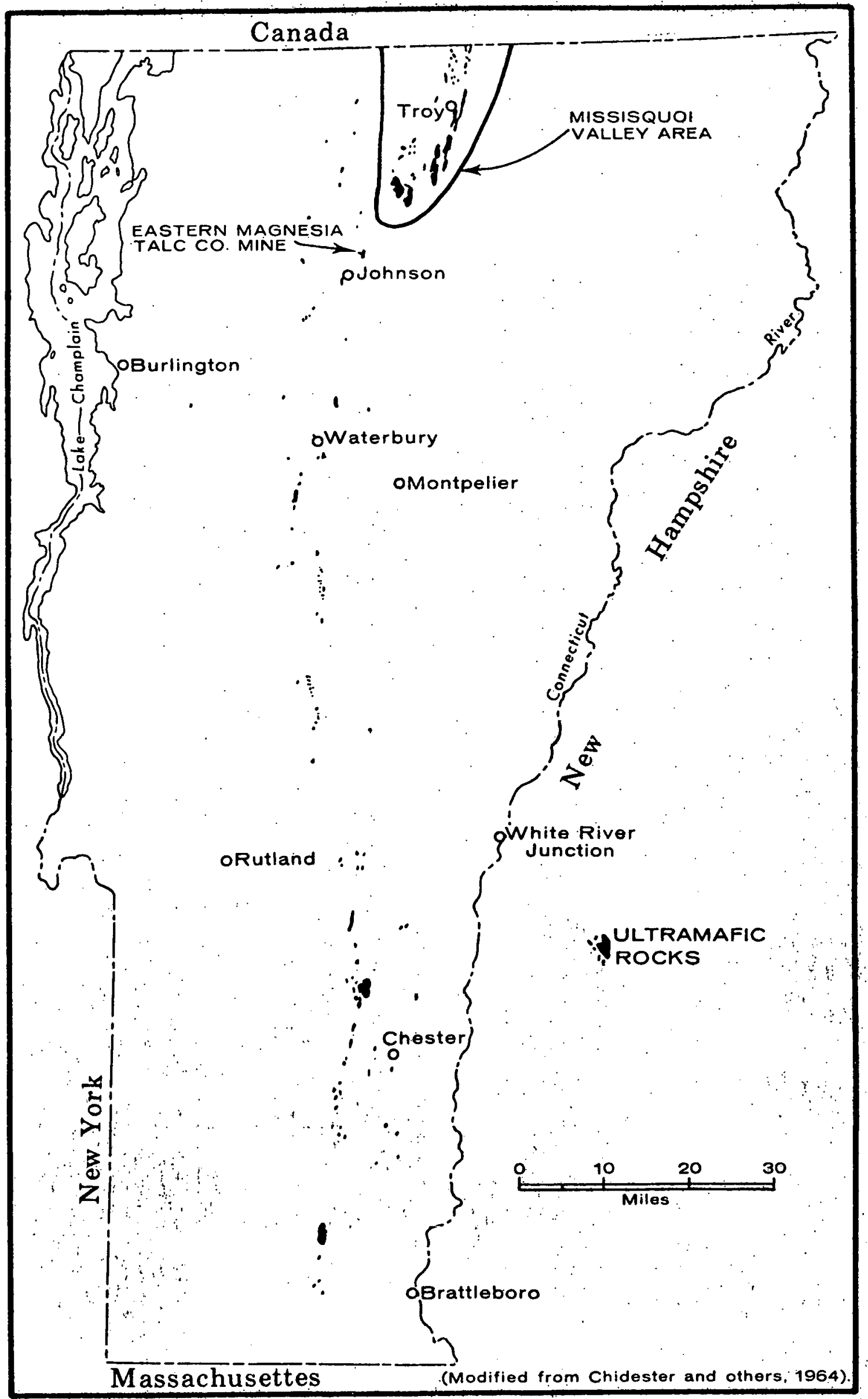

Figure 1. Index Map of Vermont Showing Occurrences of Ultramafic Bodies and the Locations of Sites Examined in this Report 
is apparently more easily eroded than the adjacent schist country rock, since this unit in general lies slightly lower topographically.

Samples of the talc-carbonate rock are white to buff-colored on the weathering surface. Fresh exposures are typically finegrained with a gray and white spotted equigranular appearance; in most samples, magnesite predominates.

This particular talc-carbonate body has never been mined for talc or any other resource (Cady and others, 1963). Furthermore, preliminary drill core investigations by the Eastern Magnesia Talc Company at two locations both north and south of state Route 100 indicate that this rock is probably too low-grade for any future commercial exploitation (Howard Shafer, personal communication).

Although not examined in detail, surface exposures of the serpentinite and dunite in this area show a wide variety of topographic expressions. Unserpentinized or partially serpentinized dunite and massive serpentinite bodies are often exposed as steep brown-colored barren ridges. This was seen, for example, at Browns Ledges (see Figure 1 of Cady and others, 1963). In other locations where schistose serpentinite is common, the ultramafic body is normally not exposed except in artificial openings. Such rock types in general show low topographic expression.

The Eastern Magnesia Talc Company Mine

The Eastern Magnesia Talc Company operation near Johnson, Vermont, a subsidiary of Engelhard Minerals and Chemicals Corporation, is one of three active mining operations for talc within the state (Fulkerson, 1972) and is the largest producer 
in the region, with a yearly production of 90,000 short tons. (Howard Shafer, personal communication). The mine is located 2.85 miles northeast of Johnson at an altitude of about 1050 feet. The mine is situated in an area of moderate relief.

The geological setting is described in detail by chidester and others (1951). The ore, which consists of steatite and grit (talc plus magnesite), averages around 62 percent talc. This ore is found within a series of steeply-dipping, on-echelon lenses that vary up to 200 feet in width and lie within a zone at least onehalf mile long. Figure 2 shows a typical cross-section of these lenses, whereas Figure 3 shows a longitudinal projection at depth. Each of these ultramafic masses has been largely altered to grit and steatite (nearly pure talc), although a few remnants of serpentinte are present (see Figure 2). The country rock consists of quartz mica schist and micaceous quartzite; chlorite schist (blackwall) occurs at the contact. This contact is abrupt. The serpentinite typically occurs as fine-grained dark green generally non-schistose rock that in turn abruptly grades into the grit. The grit, medium to light gray in color, consists of some 30 to 50 percent magnesite which is uniformly scattered throughout the rock as grains one-eighth to three-quarters of an inch diameter in a ground mass of talc.

At the present time, major mining activity occurs within several of these bodies at the fifth level, about 375 feet vertically below the surface. Access to this level is gained through a $45^{\circ}$ incline shaft. Older inactive levels lie above this 


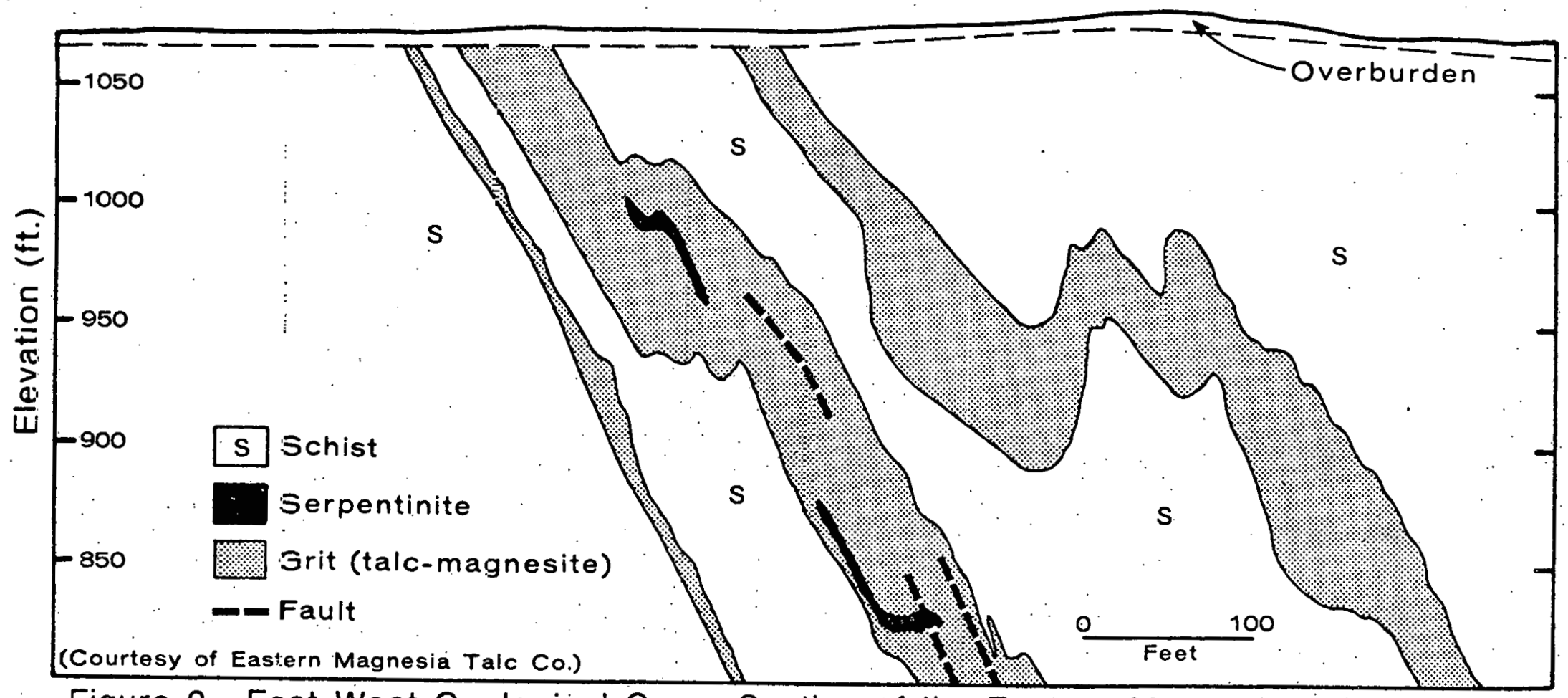

Figure 2. East West Geological Cross Section of the Eastern Magnesia Talc Company Mine above Level Five 


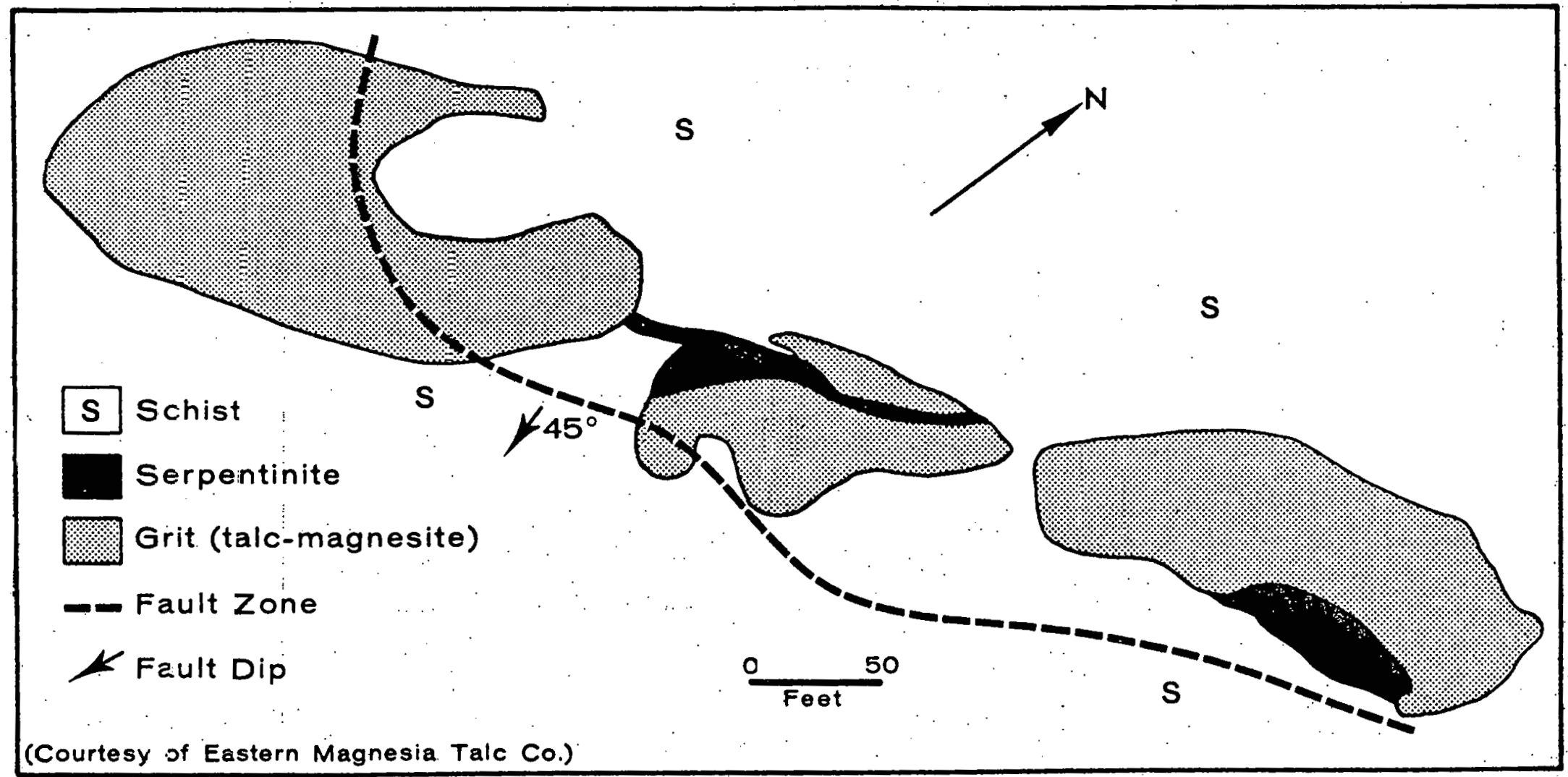

Fig'ire 3. Geologic Map of the Fifth Level of the Eastern Magnesia Talc Company Mine 
mining level. A sketch map of the geologic environment of the fifth level is shown in Figure 3 .

Drifts at level 5 are almost entirely in grit, which is massive and holds up well with little or no timbering. Principal examination in this study was made of drifts that intersect all rock types, namely the grit, serpentinite, and the country rock, in order to assess both the structure and ground-water influx of the differing rock types.

Within the mine, both serpentinite and the country rock exhibit minor jointing and fracturing and thus seems to be relatively rigid. The grit and steatite however appear to be much less compact. Within the grit, very small-scale on-echelon fractures are common (see Plates 1 and 2). Fractures observed in the serpentinite and country rock generally do not extend into the grit (see Plate 1), thus demonstrating the self-sealing properties of talcose rocks. In general, talc-bearing rocks commonly exhibit properties of flowage due to very fine-scale slippage along cleavage planes within the mineral itself.

Post-metamorphic faults are prominent in parts of the mine, as described by Chidester and others (1951) and shown on Figure 2. A major fault at the fifth level, shown on Figure 3 , cross-cuts both the grit and serpentinite and extends into the country rock. This fault is found in upper levels as well and is thought to possibly extend to the surface. Within the mine, the fault has an associated gouge zone some five to 10 feet wide. Heavy timbering has been used where drifts transect this area (see Plates 3 


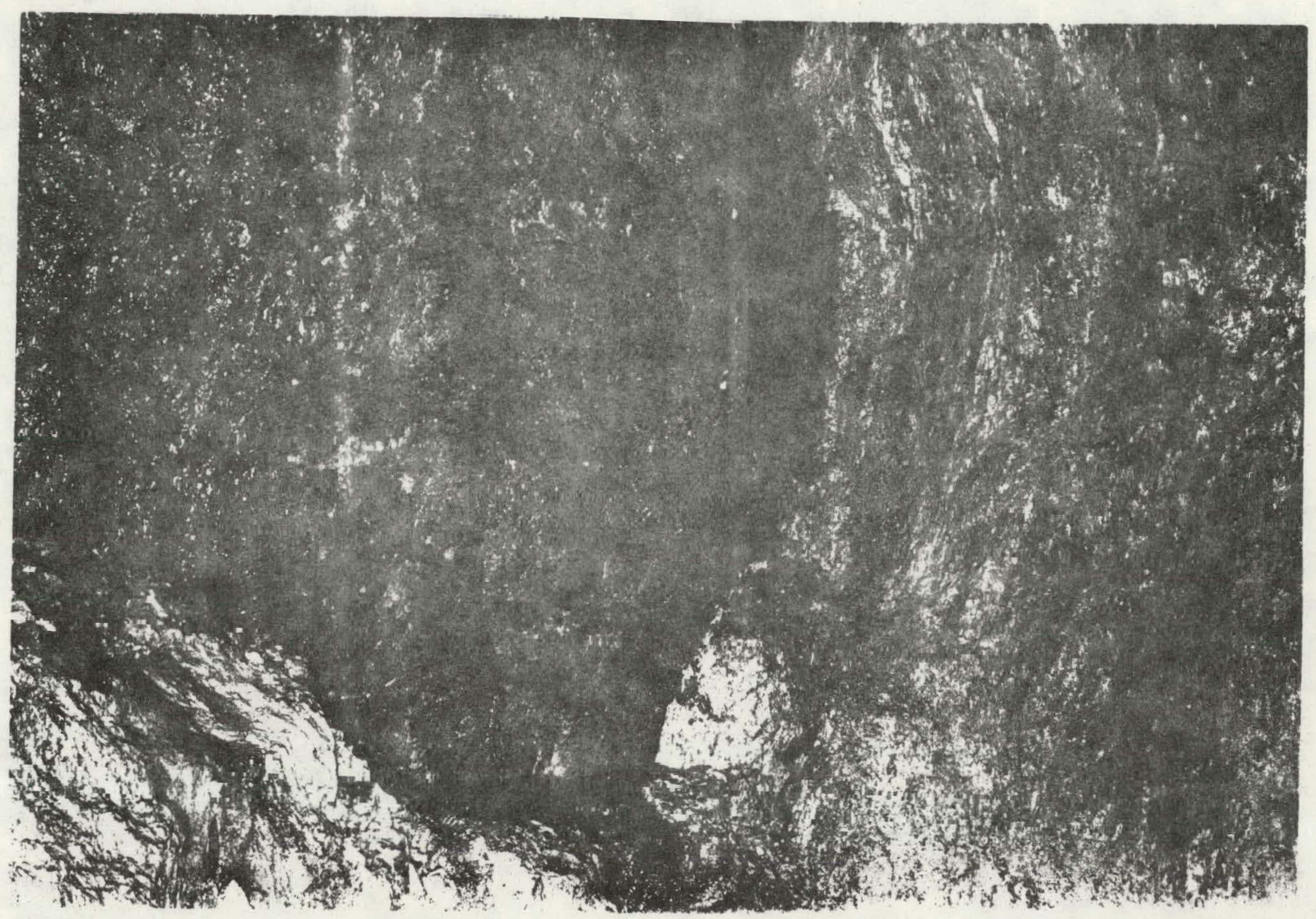

Plate 1. View of the ceiling of a fifth level drift within the Eastern Magnesia Talc Company mine showing a remuant of dark-colored massive serpentinite in contact with lighter-colored schistose grit. Note in particular that the serpentinite contains a continuous fracture that does not extend into the grit. In general, talcose rocks exhibit flowage along minute smallscale shear planes in contrast to serpentinite. Bottom edge of photograph corresponds to about 3 feet. 


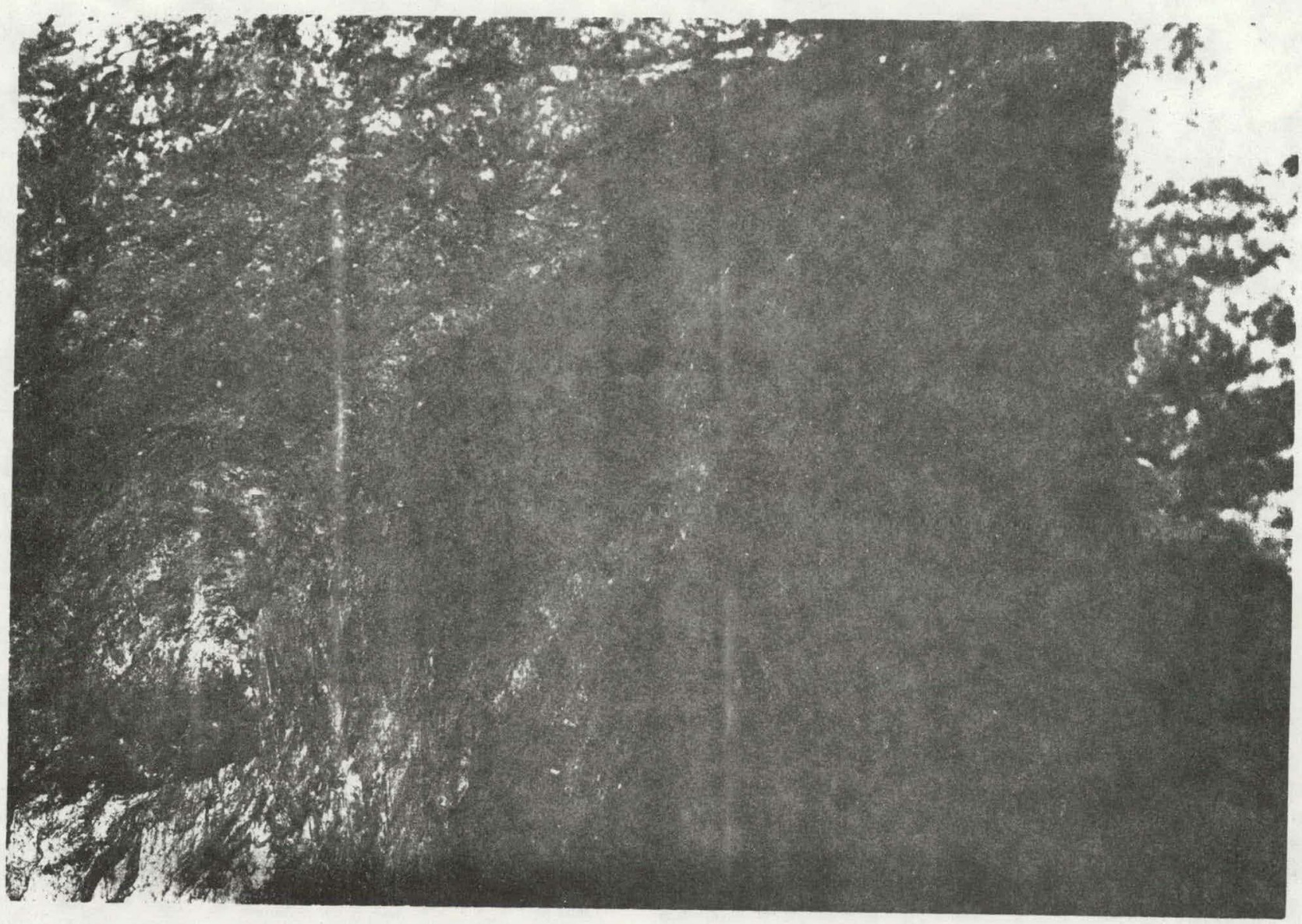

Plate 2. View within the Eastern Magnesia Talc Company mine at the end of a fifth level drift showing the gritsteatite-blackwall contact. Massive light graycolored grit in the upper left edge grades into a 2-foot thick dark, highly sheared steatite zone that extends diagonally across the view. Massive, black country rock (blackwall) is seen in the lower right hand side of the picture. Large quantities of ground water, estimated to be approximately 10 to 20 gallons per minute, can be seen flowing downward along the face of the blackwall. Field of view encompasses about 10 square feel. 
and 4). Within this zone, flowage through small-scale fracturing is causing a collapse and buckling of the mine supports (see Plate 3).

Observations of the inflow of water within the mine indicates that most enters through artificial openings; however, minor amounts of ground-water influx occur through fractures and faults, principally from upper levels. As a general rule, virtually no seepage was observed from the ceilings of drifts within the grit or serpentinite, even though the serpentinite was crosscut by small scale joints.

Some evidence of ground water percolation was noted in all of the rock types which were cross-cut by the major fault shown in Figure 3. In most instances, a slight drippage of a few drops per minute was usually observed along the ceiling of the drifts (see Plate 4), although in some areas as much as one gallon of water per minute per square yard was seen issuing from the mine ceiling. A more pronounced seepage occurred where this major fault cross-cuts the serpentinite. It is thought that most of the water comes from the flooded fourth level some 140 feet above the fifth level. A significant amount of ground-water influx, estimated from 10 to 20 gallons per minute, was also noted along the contact between the country rock and the steatite (see Plate 2). It is to be notcd, however, that not all such contacts showed this quantity of ground water percolation. Most of the water issuing from the steatite-blackwall contact is thought to be derived from through-going fractures within the country rock, 


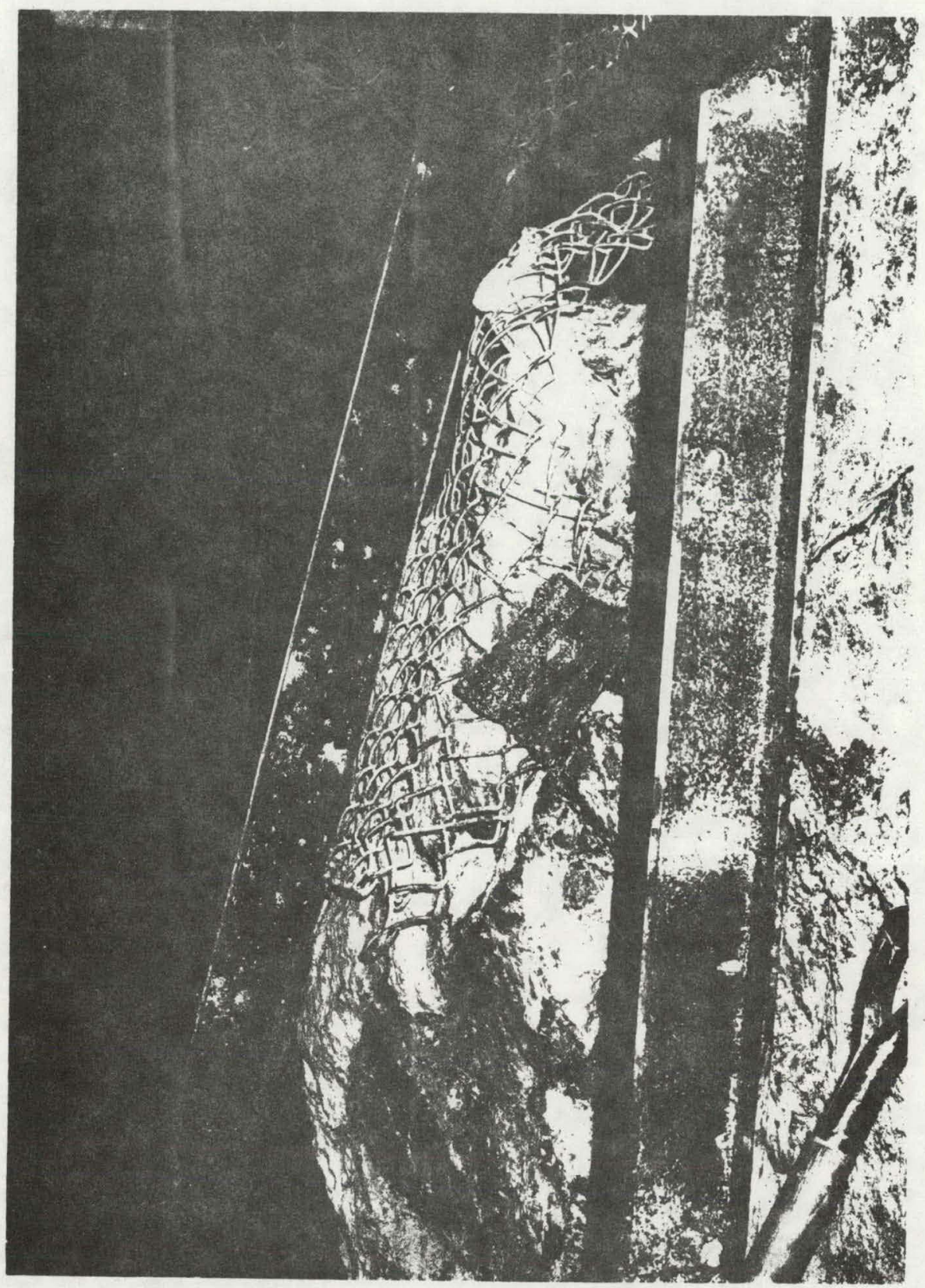

Plate 3. View of one side of a fifth level drift in the Eastern Magnesia Talc Company mine showing evidence of flowage and collapse of massive grit within a major fault zone. Grit is seen undergoing structural weakening which results in a buckling of the vertical steel supports. Area of view encompasses about 10 square feet. 


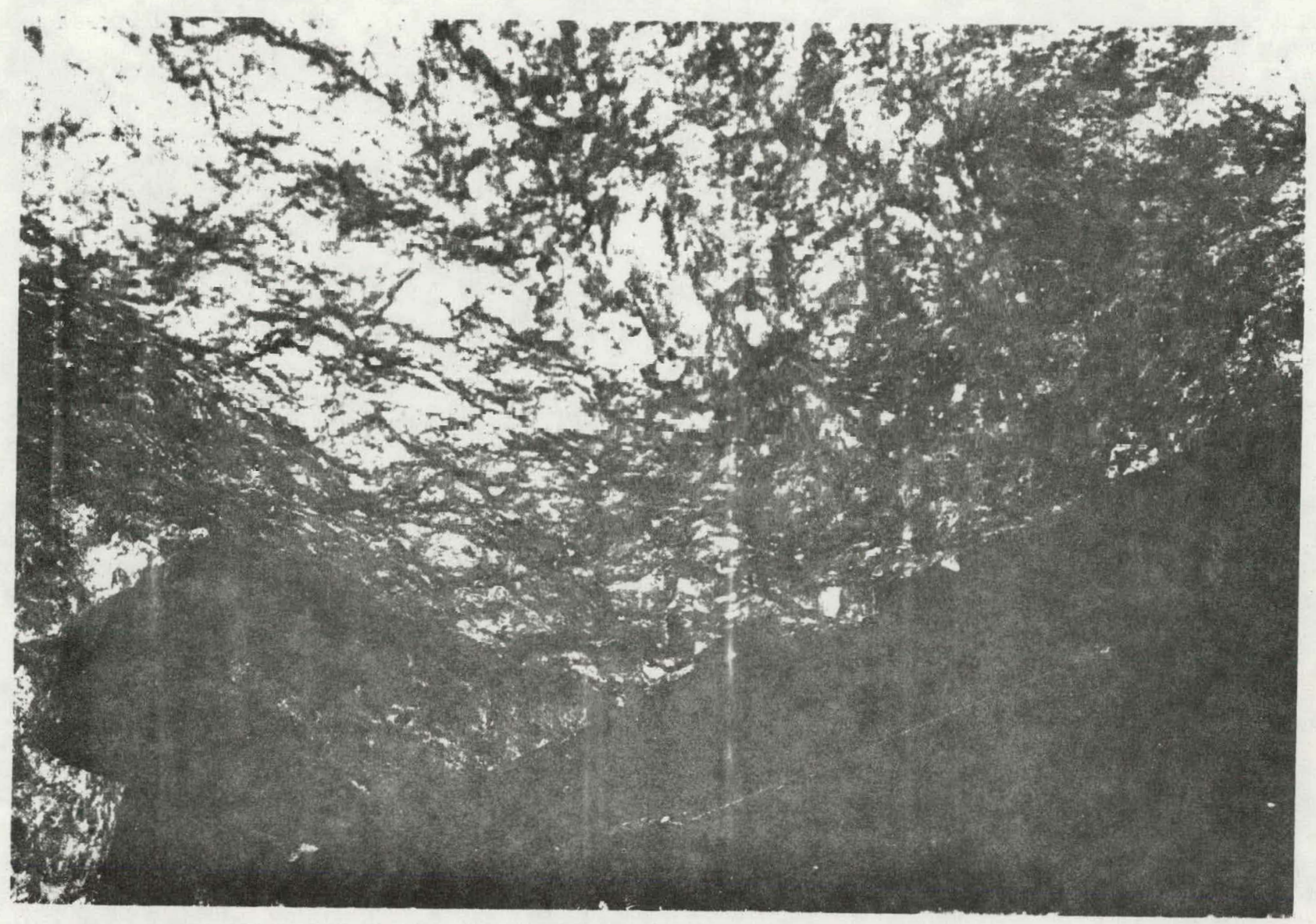

Plate 4. View of the ceiling of a fifth level drift within the Eastern Magnesia Talc Company mine. This photograph shows ground water scepage, estimated to be only a few tens of drops per minute, from a major fault zone within the grit. Area of view encompasses about 6 square feet. 
not from upper levels.

Baltimore and Northeast Maryland

After discussions with personnel of the Maryland Geological Survey and the Pennsylvania Geological Survey, it was apparent that the best overall observations of serpentine and talc bodies within this general region could be made in the vicinity of Baltimore and in northeast Maryland near the Pennsylvania state line. Thus, selected localities within several of the ultramafic bodies described in the previous report and shown on the geologic maps of Pearre and Heyl (1960) are discussed in the following. sections.

(1) One location within the Bare Hills serpentinite body, a small 1 1/4 mile long by $1 / 2$ mile wide ellipsoid mass located three miles north of the city limits of Baltimore, was examined. Several quarries and mines, al1 inactive since the early 1950s, are 1ocated within this unit; detailed observations were made in a quarry located on the west side of Falls Road at the northern edge of the body (see Kuff, 1975, for an exact location of this and other sites in the vicinity of Baltimore).

The serpentinite is typically a bluish-black and green massive rock that is well-jointed and irregularly fractured. Most of the fractures appear to be aligned with the foliation of the schist country rock that lies to the north. Surface exposures of the serpentinite in this locality suggest a strength and resiliency similar to many other crystalline rocks. Apparently this quarry 
site is typical of the whole serpentinite mass, although small amounts of soapstone are described as occurring in this body (Pearre and Heyl, 1960).

(2) Several inactive quarries near Marriottsville llocations 5 and 6 on Figure 40 of Pearre and Heyl, 1960) were examined. These exposures represent a small section of the northeastoriented $20 \mathrm{mile}$ long lenticular ultramafic body that extends along the west edge of Baltimore County and southward through Howard County. This body is relatively narrow ( $1 / 4 \mathrm{mile})$ throughout most of its length, but becomes broader $(2$ miles wide) at its northern extremity. This northern section, referred to as the Soldiers Delight District (Pearre and Heyl, 1960), is composed principally of massive serpentinite, whereas the thinner parts of the body contain abundant chlorite-talc schists; the sites examined in this study were representative of the latter rock types.

Both quarries, excavations some 600 feet (location 5) and 250 feet (location 6) wide, expose soapstone and chlorite and talc schists; at both sites, the rock exhibits a steeply dipping foliation. Areas adjacent to these excavations, which were not mined, consist of dark greenish-black chlorite schist. within the quarries themselves, fine intergradational sequences of soft greenish-gray relatively pure talc alternated with harder dark green chlorite-talc schists; these sequences varied from several feet to tens of feet thick. Interspersed with these sequences are veins and pods of quartz and carbonates up to several feet wide: 
(3) One section of the ultramafic rock body that lies within the state Iine District was examined in a two-mile traverse along the north side of the Susquehanna River. This traverse extended across a $3 / 4$ mile wide zone of serpentinite in contact with gabbro (Pearre and Heyl, 1960). The ultramafic body is part of a major northeast-trending unit that extends some $20 \mathrm{miles}$ from the Jarrettsville-Dublin District in Maryland to southeastern Pennsylvania.

Observations along the traverse indicate that the ultramafic rock-gabbro contact is gradational. Furthermore, it would appear that most of the unit described by Pearre and Heyl (1960) as being composed of ultramafic rocks consists predominantly of gabbro. Distinction between the ultramafic rocks and gabbros could be made both in fresh samples, by the mineral content, or on partially weathered surfaces; gabbro typically weathers to a greenish-white color, whereas serpentinite has a characteristically dark greenishblack appearance. Both the serpentinite and gabbro were observed to be massive and highly-jointed throughout the traverse.

A small quarry in the ultramafic rock unit, the Bald Friar Quarry (location 25 on Plate 41 of Pearre and Heyl, 1960), is exposed along the river's edge. The ultramafic rocks are intruded by albitite dikes which are locally altered to talc schist along a 6- to 12-inch thick border zone. Very little talc schist was observed in this quarry since most has been removed during mining. 


\section{Eastern California Talc Deposits}

Although not covered in the original report, several deposits in this area were examined in order to gain further insight into geologic environments where talc is typically associated with metasedimentary type rocks. These talc deposits would in all probability not be suitable as waste repositories due to their relatively small dimensions (their maximum thicknesses are normally less than 80 feet; see Chidester and others, 1964), the high seismic risk of the region (seismic risk zone 3 encompasses all of the California talc deposits), and due to extensive man-made excavations.

The major talc deposits in California occur in three principal regions, described in detail by Chidester and others (1964). " These include the Silver Lake-Yucca Grove District, the Southern Death Valley-Kingston Range District, and the Inyo Range-Northern Panamint Range District. Mines, within the latter two districts were examined.

The talc deposits within the Southern Death Valley-Kingston Range District are confined to mildely metamorphosed massive carbonate rocks that are intruded by diabase sills. The talc occurs near the contact as replacement bodies in silicified carbonate. Inspection was made of the Western Mine, located some five miles east of Tacopa, California (location.60, Plate 2 from Chidester and others, 1964). This mine consists of two main steeply dipping ore bodies more than 5000 and 3000 feet 10 ng; each varies from 10 to 80 feet wide. Both have been strip-mined to an approximate depth of around 350 feet. The ore consists of 
laminated talc schist in massive tremolite-rich rock. This operation is presently inactive, although over 300,000 tons were mined through 1959.

The talc deposits within the Inyo Range-Northern Panamint Range District represent replacement bodies in dolomite in which the talc has been developed along shear and fracture zones (see Chidester and others, 1964). Examination was made in the vicinity of the Talc City Mine; in this region, some 260,000 tons have been mined through 1955. This area is currently being mined in several relatively small open pit excavations. older underground operations in the area are now inactive. The ore is found in numerous vertically dipping lenses, the largest being 500 feet long by about 50 feet wide. These lenses, which consist of a greenish-colored nearly pure talc ore, are associated with dolomite and less pure white talc and carbonate rock. 


\section{CONCLUSIONS AND RECOMMENDATIONS}

The following conclusions and recommendations are based upon the information contained both in this report and the previous study relating to the potential usage of talc and ultramafic rocks for the containment of radioactive wastes. Additional comments are included for consideration of some other crystalline-rock types as well.

(I) Ultramafic rocks and serpentinites would appear to have many favorable features that make them worthy of further consideration. Such rock types are widely distributed in many regions of the country and many units are relatively large in size. 'Furthermore these rocks display wide variations in their physical properties, based largely on the degree of serpentinization and mineral content. For example, serpentinite would appear to have certain self-sealing and flowage characteristics that render it impermeable at depth, whereas unserpentinized.ultramafic rocks are structurally very rigid and strong. Another favorable property of ultramafic rocks is the relatively low thermal expansion coefficient; this factor is extremely important since differential heating may lead to fracturing due to thermal stresses.

A great deal of additional information relating to flowage characteristics and the impermeability of serpentinites and ultramafic rocks could be gained from on-site studies in deep mines. Although none are known in the U. S., several can be found in Canada and other countries. In addition, detailed field studies of surface exposures of potentially suitable ultramafic rock. bodies 
could provide such crucial information as the distribution of serpentine throughout the ultramafic bodies, the existence of large fracture and fault zones, and the variation in mineral assemblages.

To complement this study, additional consideration should also probably be given to ultramafic bodies in other parts of the U. S. Particular interest should be extended to those areas of relatively low seismic risk (i.e., Texas, wyoming).

(2) Talc also has some favorable features and characteristics such as a high thermal stability and a low porosity and permeability. This present study has verified that very. little ground water influx occurs in talcose rocks except in large fault zones. Even in these instances, such as was observed in the Eastern Magnesia Talc Company mine, only a very slight seepage occurred due to percolation. from flooded upper levels in the mine.

A major drawback for the usage of talc for containment of radioactive wastes is due to the relatively small sizes of most bodies. However, some of the large talc-carbonate units in the Missisquoi Valley Region of Vermont may be potentially useful if adequate subsurface information could be obtained.

(3) Consideration should also be given to other crystalline rocks as well, particularly schists, since they commonly contain micaceous materials which have similar properties to talc and serpentine. Insight into the favorability of such rocks could probably best be gained from subsurface observations in deep mines. In such instances, one could learn a great deal about two very cructal factors, namely the structure of the rock under 
pressure and ground water percolation at depth. In considering other crystalline rock types, however, complementary.studies have to be made of surface outcrops in order to ascertain large scale compositional variations and structural features.

(4) In considering various types of rocks for containment of radioactive wastes, certain attention should also be given to laboratory-type investigations as well. Although certain physical properties are known for some kinds of rocks, it is essential that they be assembled or measured for all potentially suitable rock types. The properties that would seem to be of most importance to this whole problem are thermal conductivities, thermal expansion coefficients, and the thermal stabilities. Of extreme importance is understanding how high radiation fluxes affect and alter these physical properties. 


\section{ACKNOWLEDGMENTS}

Sincere appreciation is extended to Dr. Maurice L. Morency for discussions relating to serpentinites and ultramafic rocks. Much information concerning the nature of talc was gained through examination of the underground mine operations of the Eastern Magnesia Talc Company; sincere appreciation is extended to this company and to Howard Shafer. Appreciation is also extended to Ms. Karen Kuff and other personnel of the Maryland Geological Survey. 


\section{REFERENCES CITED}

Cady, W. M., Albee, A. L., and Chidester, A. H., 1963, Bedrock geology and asbestos deposits of the Upper Missisquoi Valley and vicinity, Vermont: U. S. Geol. Survey Bull, 1122-B, $78 \mathrm{p}$.

Chidester, A. H., Billings, M. P., and Cady, W. M., 1951, Talc investigations in vermont--preliminary report: U. S. Geol. Survey Circ. $95,33 \mathrm{p}$.

Chidester, A. H., Engel, A. E. J., and Wright, L. A., 1964, Talc resources of the United States: U. S. Geol. Survey Bull. $1167,61 \mathrm{p}$.

Fulkerson, F. B., 1972, The mineral industry of Vermont; in Minerals Yearbook for 1972: U. S. Bureau of Mines, Area Reports, v. II, p. 1-4.

Kuff, K., 1975, Mined land inventory map of Baltimore County and Baltimore City, Maryland Geological Survey.

Pearre, N. C., and Heyl, A. V., 1960, Chromite and other mineral deposits in serpentine rocks of the Piedmont upland Maryland, Pennsylvania, and Delaware: U. S. Geol. Survey Bull. 1082-K, p. 707-8.33. 